\title{
PERBEDAAN KEMAMPUAN MENULIS TEKS TANGGAPAN KRITIS SIWA KELAS IX SMPN 3 BENGKULU UTARA DENGAN SISWA KELAS IX SMPN 10 BENGKULU UTARA
}

\author{
Oktarina Widarsih, Syukri Hamzah, dan Didi Yulistio \\ Program Studi Pendidikan Bahasa dan Sastra Indonesia \\ Jurusan Pendidikan Bahasa dan Seni \\ FKIP Universitas Bengkulu \\ oktarinabengkulu@gmail.com
}

\begin{abstract}
Abstrak
Tujuan penelitian ini: 1) untuk mengetahui kemampuan menulis teks tanggapan kritis siswa kelas IX SMPN 10 Bengkulu Utara, 2) untuk mengetahui kemampuan menulis teks tanggapan kritis siswa kelas IX SMPN 3 Bengkulu Utara, dan 3) untuk mengetahui perbedaan kemampuan menulis teks tanggapan kritis antara siswa kelas IX SMPN 3 Bengkulu Utara dan siswa kelas IX SMPN 10 Bengkulu Utara. Penelitian ini menggunakan metode deskriptif kuantitatif. Populasi penelitian ini adalah siswa kelas IX SMPN 3 Bengkulu Utara dan kelas siswa IX SMPN 10 Bengkulu Utara, sampel diambil sebanyak 100 siswa. Teknik pengumpulan data menggunakan tes kemampuan menulis teks tanggapan kritis. Teknik analisis data yang digunakan adalah T-tes tidak berpasangan. Hasil penelitian menunjukkan bahwa kemampuan menulis teks tanggapan kritis pada siswa kelas IX SMPN 3 Bengkulu Utara berkategori cukup dan siswa kelas IX SMPN 10 Bengkulu Utara berkategori baik. Tidak terdapat perbedaan yang signifikan antara siswa kelas IX SMP 3 Bengkulu Utara dengan siswa kelas IX SMP 10 Bengkulu Utara. Saran yang diajukan untuk kedua sekolah tersebut yaitu lebih memahami struktur teks, kaidah-kaidah bahasa, serta ejaan Bahasa Indonesia agar tulisan siswa lebih berkualitas.
\end{abstract}

Kata kunci: Perbedaan,Kemampuan Menulis, Teks Tanggapan Kritis

\begin{abstract}
The purpose of this research is 1) to know the ability to write text of critical responses of students of class IX SMPN 10 Bengkulu Utara, 2) to know the ability to write text of critical responses of students of class IX SMPN 3 Bengkulu Utara and 3) to know the difference of writing ability of critical responses between students Class IX SMPN 3 North Bengkulu and students of class IX SMPN 10 North Bengkulu. This research uses quantitative descriptive method. The population of this research is the students of IX class SMPN 3 Bengkulu Utara and the students class IX SMPN 10 Bengkulu Utara, the sample is taken as many as 100 students. Data collection techniques use critical capability writing text tests. The data analysis technique used is unpaired T-test. The results showed that the ability to write text critical responses in students of class IX SMPN 3 Bengkulu North categorized enough and students class IX SMPN 10 North Bengkulu good category. There was no significant difference between students of IX class 3 of SMP 3 Bengkulu Utara with students of class IX SMP 10 Bengkulu Utara. From the results of this study as for suggestions submitted for both schools are more understanding of the structure of text, language rules, and spelling of Indonesian so that the writings of students more qualified.
\end{abstract}

Keywords: Differences, Writing Capabilities, Critical Response Texts 


\section{PENDAHULUAN}

Kemampuan menulis merupakan kebutuhan bagi setiap individu. Oleh karena itu, kemampuan menulis merupakan kemampuan yang harus dikuasai. Setiap siswa perlu belajar menulis secara baik dan efektif. Penulis perlu memiliki banyak ide dan pengetahuan. Hal ini merupakan modal dasar yang harus dimiliki dalam kegiatan menulis. Di samping itu, seorang penulis harus menguasai banyak perbendaharaan kata untuk menyampaikan ide-ide, pengetahuan, serta pengalaman yang dimiliki, karena menulis menurut Mc. Crimmon (Saddhono dan slamet, 2012:96) merupakan kegiatan menggali pikiran dan perasaan mengenai suatu objek, memilih hal-hal yang akan ditulis, menentukan cara menuliskannya sehingga pembaca dapat memahaminya dengan mudah dan jelas.

Kurikulum 2013 untuk mata pelajaran Bahasa Indonesia menggunakan teks sebagai sarana pembelajaran. Oleh karena itu, dapat dinyatakan bahwa Kurikulum 2013 untuk mata pelajaran Bahasa Indonesia berbasis teks. Permendikbud No. 68 Tahun 2013 menyatakan dinyatakan bahwa pada jenjang SMP/MTs terdapat 14 jenis teks, yang terdiri dari teks eksemplum, tanggapan kritis, tantangan, rekaman percobaan, cerita moral/fabel, ulasan, diskusi, cerita prosedur, cerita biografi, hasil observasi, tanggapan deskriptif, eksposisi, tanggapan kritis, dan cerita pendek. Teks tanggapan kritis yang dipelajari pada kelas IX. Pada teks ini siswa diminta untuk memberikan atau menyampaikan kritik terhadap fenomena alam atau pun sosial yang berada di sekitarnya. Kritik yang disampaikan hendaklah kritik yang membangun sehingga dapat mengarahkan atau membimbing seseorang atau sekelompok orang ke arah yang lebih baik. Selain itu dalam pembelajaran teks ini, terdapat nilai karakter bangsa yang dikembangkan yaitu demokratis, kreatif, santun dan cinta tanah air, maka dari itu pembelajaran teks tanggapan kritis menjadi suatu hal yang penting bagi siswa untuk membentuk karakternya.

Adapun kompetensi dasar yang diturunkan dari kompetensi inti, salah satu di antaranya kemampuan memproduksi teks, yang berarti siswa mampu menghasilkan teks dengan ciptaannya sendiri, sehingga keterampilan menulis memiliki posisi yang penting karena dapat meningkatkan keterampilan siswa dalam menulis teks.

Pada penelitian ini penulis akan mengamati pada tahap keempat dalam kegiatan menulis teks secara mandiri. Pada tahap ini siswa diharapkan dapat mengaktualisasi diri dengan menggunakan teks sesuai dengan jenis dan ciri-ciri seperti yang ditunjukkan pada model.

Berdasarkan paparan di atas penulis tertarik untuk melakukan penelitian deskritif komparatif dalam pengajaran bahasa Indonesia yang berjudul "Perbedaan Kemampuan Menulis Teks Tanggapan Kritis Antara Siswa Kelas IX SMPN 3 Bengkulu Utara dan Siswa Kelas IX SMPN 10 Bengkulu Utara" yang didasarkan pada hasil UN Bahasa Indonesia siswa kedua sekolah tersebut yang relatif masih kurang memuaskan, yakni nilai yang dicapai rata-rata siswa pada SMPN 3 Bengkulu Utara yaitu 65,07 dan SMPN 10 Bengkulu Utara yaitu 67,14.

\section{METODE}

Penelitian ini menggunakan metode penelitian deskriptif kuantitatif dengan melakukan perbandingan yang bertujuan untuk mengetahui perbedaan hasil belajar menulis pada dua sekolah yang berbeda, yaitu kelas IX SMPN 3 Bengkulu Utara dan kelas IX SMPN 10 Bengkulu Utara.

Populasi dalam penelitian ini adalah seluruh siswa kelas IX SMPN 3 Bengkulu 
Utara dan siswa kelas IX SMPN 10 Bengkulu Utara. dapat diketahui bahwa terdapat 249 jumlah yang menjadi populasi penelitian ini. Dalam penelitian ini, peneliti memilih sampel terjangkau yang diambil secara acak/random terjangkau dengan 50 siswa dari SMPN 3 Bengkulu Utara adan 50 siswa dari SMPN 10 Bengkulu Utara dengan teknik undian.

Penelitian ini dilaksanakan di kelas IX Sekolah Menengah Pertama Negeri 3 Bengkulu Utara, yang beralamatkan di Jalan Kol. Alamsyah Sh No 01, Gunung Agung, Kecamatan Argamakmur, dan di kelas IX Sekolah Menengah Pertama Negeri 10 Bengkulu Utara yang beralamatkan di Jalan Raya Lubuk Durian, Kecamatan Kerkap. Pelaksanaan penelitian ini pada bulan Maret 2017.

Pengumpulan data menggunakan teknik tes, yang bertujuan untuk melihat hasil menulis teks tanggapan kritis siswa. Tes tersebut dilaksanakan dengan menugaskan siswa untuk membuat teks tanggapan kritis.

Adapun hipotesis statistik yang diajukan adalah:

Ho: $t_{0} \leq t_{t}$

$\mathrm{H}_{2}: \mathrm{t}_{\mathrm{o}}>\mathrm{t}_{\mathrm{t}}$

Deskripsi mengenai kemampuan menulis teks tanggapan kritis siswa, maka dilakukan dengan cara:

(a) Memberikan Penilaian Terhadap hasil menulis teks tanggapan kritis siswa.

(b) Penilaian dilakukan oleh dua orang, peneliti sendiri dan guru bahasa indonesia yang mengajar di kelas.

(c) Menggabungkan skor penilaian dari dua orang penilai yakni, peneliti sendiri dan guru bahasa indonesia yang mengajar di kelas.

(d) Mencari nilai rata-rata dari hasil penilaian kemampuan menulis teks tanggapan kritis siswa. Menghitung nilai rata-rata dapat dilakukan dengan cara sebagai berikut:
Keterangan:

$\mathrm{M}=$ rata-rata nilai

$\Sigma \mathrm{x}=$ jumlah nilai

$\mathrm{N}$ = jumlah siswa (aspek penilaian)

e. Kategori kemampuan menulis teks tanggapan kritis setiap siswa ditentukan berdasarkan tabel di bawah ini:

Tabel 2. Kategori Kemampuan Menulis Teks Tanggapan kritis

\begin{tabular}{|l|l|l|}
\hline No & $\begin{array}{l}\text { Skor Kemampuan } \\
\text { Tingkat Penguasaan }\end{array}$ & Kategori \\
\hline 1 & $81-100$ & Sangat Baik \\
\hline 2 & $61-80$ & Baik \\
\hline 3 & $41-60$ & Cukup \\
\hline 4 & $21-40$ & Kurang \\
\hline 5 & $1-20$ & $\begin{array}{l}\text { Sangat } \\
\text { Kurang }\end{array}$ \\
\hline
\end{tabular}

- (e) Selanjutnya hasil kemampuan menulis teks tanggapan kritis siswa diuji dengan $t$ test.

\section{a. Uji Persyaratan Analisis}

a) Uji Normalitas

Uji normalitas sebagai persyaratan, dalam penelitian ini menggunakan uji normalitas Kolmogorof Smirnov.

\section{b) Uji Perbedaan}

Uji beda dilakukan untuk mengetahui apakah terdapat perbedaan rata-rata hasil belajar antara siswa kelas IX SMPN 3 Bengkulu Utara dengan siswa kelas IX SMPN 10 Benngkulu Utara (Arikunto, 2010:349).

\section{HASIL DAN PEMBAHASAN \\ Hasil Penelitian}

Kemampuan Menulis Teks Tanggapan Kritis Siswa Kelas IX SMP 3 Bengkulu Utara

Hasil perhitungan tersebut nilai rata-rata yang didapatkan siswa kelas IX SMPN 3 Bengkulu Utara adalah 59,48 yaitu berkategori cukup. Keterangan cukup didapatkan karena siswa rata-rata cukup menguasai permasalahan, cukup memadai, pengembangan observasi terbatas, relevan dengan topik namun kurang rinci. Rata- 
rata Struktur teks siswa tidak lengkap tetapi tersusun secara sistematis. Rata-rata Penguasaan kata memadai, pilihan, bentuk, dan penggunaan kata/ungkapan kadang-kadang salah namun tidak mengganggu. Rata-rata konstruksi sederhana namun efektif, terdapat kesalahan kecil pada konstruksi kompleks, terjadi sejumlah kesalahan penggunaan bahasa (fungsi/urutan kata, artikel, pronomina, preposisi) namun makna cukup jelas. Kadang-kadang siswa terjadi kesalahan ejaan, tanda baca, penggunaan huruf kapital, dan penataan paragraf, namun tidak mengaburkan makna.

Adapun hasil analisis kemampuan teks tanggapan kritis msing-masing aspek sebagai berikut:

\section{Aspek Isi}

Hasil perhitungan diperoleh rata-rata kemampuan menulis teks tanggapan kritis siswa kelas IX SMPN 3 Bengkulu Utara pada aspek isi sebesar 16,8. Dengan demikian, sekolah ini dalam aspek menulis dalam kategori cukup. terdapat 0 untuk sangat baik, 13 baik, 32 cukup, 5 kurang dan 0 sangat kurang.

\section{Aspek Struktur}

Hasil perhitungan diperoleh rata-rata kemampuan menulis teks tanggapan kritis siswa kelas IX SMPN 3 Bengkulu Utara pada aspek struktur sebesar 10,9. Dengan demikian, dalam aspek menyusun struktur pada sekolah ini termasuk dalam kategori cukup. Terdapat 2 siswa sangat baik, 10 siswa berkategori baik, 23 siswa berkategori cukup, 15 berkategori kurang dan 0 untuk kategori sangat kurang dari 50 siswa.

\section{Aspek Kosa Kata}

Hasil perhitungan diperoleh rata-rata kemampuan menulis teks tanggapan kritis siswa kelas IX SMPN 3 Bengkulu Utara pada aspek kosa kata sebesar 12,4. Dengan demikian, dalam aspek kosa kata sekolah ini termasuk dalam kategori cukup. Terdapat 22 siswa berkategori baik, 28 siswa berkategori cukup, dan 0 untuk kategori sangat baik, kurang, sangat kurang dari 0 .

\section{Aspek Kalimat}

Hasil perhitungan diperoleh ratarata kemampuan menulis teks tanggapan kritis siswa kelas IX SMPN 3 Bengkulu Utara pada kalimat sebesar 12,3. Dengan demikian, dalam aspek kalimat sekolah ini termasuk dalam kategori cukup. Terdapat 0 siswa sangat baik , 17 siswa berkategori baik, 32 siswa atau berkategori cukup, 1untuk kategori kurang dan 0 untuk sangat kurang dari 50 siswa yang menjadi sampel.

\section{Aspek Mekanik}

Hasil perhitungan diperoleh ratarata kemampuan menulis teks tanggapan kritis siswa kelas IX SMPN 3 Bengkulu Utara pada mekanik sebesar 6,6. Dengan demikian, kedua sekolah ini dalam aspek menyusun struktur termasuk dalam kategori cukup. terdapat 18 siswa berkategori baik, 32 siswa berkategori cukup dan 0 untuk kategori sangat baik, kurang dan sangat kurang dari 50 siswa yang menjadi sampel.

\section{Kemampuan Menulis Teks Tanggapan Kritis Siswa Kelas IX SMP 10 Bengkulu Utara}

Hasil perhitungan $\mathrm{t}$ nilai rata-rata yang didapatkan siswa kelas IX SMPN 10 Bengkulu adalah 62,68 yaitu berkategori Baik Keterangan baik didapatkan karena siswa rata-rata menguasai topik tulisan cukup memadai, substantif, pengembangan teks tanggapan kritis lengkap, relevan dengan topik yang dibahas. Rata-rata siswa memiliki struktur teks lengkap dan tersusun secara sistematis, terdapat sedikit kesalahan. Penguasaan kosa kata memadai, pilihan 
kata dan ungkapan efektif, menguasai pembentukan kata. Dalam membuat kalimat rata-rata siswa Konstruksi kompleks dan efektif, terdapat hanya sedikit kesalahan penggunaan bahasa (urutan/fungsi kata, artikel, pronomina, preposisi). Dalam mekanik, rata-rata siswa menguasai aturan penulisan, terdapat sedikit kesalahan ejaan, tanda baca, penggunaan huruf kapital, dan penataan paragraf. Selain itu siswa juga mampu menuliskan tulisannya dengan diksi dan EYD.

Adapun hasil analisis kemampuan teks tanggapan kritis siswa kelas IX SMP 10 Bengkulu Utara sebagai berikut:

\section{Aspek Isi}

Dari hasil perhitungan tersebut diperoleh rata-rata kemampuan menulis teks tanggapan kritis siswa kelas IX SMPN 10 Bengkulu Utara pada aspek isi sebesar 17,7. Dengan demikian, sekolah ini dalam aspek menulis dalam kategori cukup. terdapat 18 siswa berkategori baik, 27 siswa berkategori cukup, 5 berkategori kurang, dan 0 untuk kategori sangat baik dan sangat kurang dari 50 siswa yang menjadi sampel

\section{Aspek Struktur}

Hasil perhitungan diperoleh ratarata kemampuan menulis teks tanggapan kritis pada siswa kelas IX SMPN 10 Bengkulu Utara sebesar 12,0. Dengan demikian, sekolah ini dalam aspek menyusun struktur termasuk dalam kategori cukup. terdapat 15 siswa berkategori baik, 23 siswa berkategori cukup, dan 3 berkategori kurang dan 0 untuk sangat baik dan sangat kurang dari 50 siswa yang menjadi sampel.

\section{Aspek Kosa Kata}

Hasil perhitungan rata-rata kemampuan menulis teks tanggapan kritis pada aspek kosa kata siswa kelas IX SMPN
10 Bengkulu Utara sebesar 13,0. Dengan demikian, kedua sekolah ini dalam aspek kosa kata termasuk dalam kategori baik. Terdapat 27 siswa berkategori baik, 23 berkategori cukup dan 0 untuk kategori sangat baik, kurang dan sangat kurang dari 50 siswa yang menjadi sampel.

\section{Aspek Kalimat}

Hasil perhitungan diperoleh rata-rata kemampuan menulis teks tanggapan kritis pada siswa kelas IX SMPN 10 Bengkulu Utara sebesar 13,0. Dengan demikian, sekolah ini dalam aspek kosa kata termasuk dalam kategori baik. Terdapat 0 siswa berkategori sangat baik, 25 siswa berkategori baik dan 25 siswa cukup, dan 0 untuk kategori kurang dan sangat kurang dari 50 siswa yang menjadi sampel.

\section{Aspek Mekanik}

Hasil perhitungan tersebut diperoleh rata-rata kemampuan menulis teks tanggapan kritis siswa pada siswa kelas IX SMPN 10 Bengkulu Utara sebesar pada aspek mekanik 6,7. Dengan demikian, sekolah ini dalam aspek menyusun struktur termasuk dalam kategori cukup. Terdapat 19 siswa berkategori baik dan 31 siswa berkategori cukup, dan 0 untuk kategori sangat baik, kurang dan sangat kurang dari 50 siswa yang menjadi sampel.

\section{Uji Perbedaan \\ Uji Persyaratan Analisis}

\section{Uji Normalitas}

Hasil perhitungan kolmogorov-smirnov dari tabel 6 di atas dapat dilihat bahwasanya, pada SMPN 3 Bengkulu Utara diperoleh $D_{\text {maks }}=0,009359$ dan $D_{\text {tabel }}=0,190$ dengan taraf signifikan $\alpha=$ 0,05 . Jika Ho diterima dan Ha ditolak maka data berdistribusi normal dan sebaliknya jika Ho ditolak dan $\mathrm{Ha}$ diterima data berdistribusi tidak normal. Berdasarkan data yang diperoleh pada tes awal $D_{\text {maks }}<$ $D_{\text {tabel }}$ yaitu $0,046945<0,270$ maka Ho 
diterima dan Ha ditolak sehingga data tes SMPN 3 Bengkulu Utara berdistribusi normal.

Pada SMPN 10 Bengkulu Utara diperoleh $D_{\text {maks }}=-0,00183$ dan $D_{\text {tabel }}=$ 0,190 dengan taraf signifikan $\alpha=0,05$ pada $\mathrm{N}=50$. Berdasrakan data yang diperoleh pada tes awal $D_{\text {maks }}<D_{\text {tabel }}$ yaitu $-0,00183<0,190$ maka Ho diterima dan $\mathrm{Ha}$ ditolak sehingga data SMPN 10 Bengkulu Utara yang diperoleh berdistribusi normal.

\section{Uji T-Test}

Dapat dilihat bahwa uji t yang telah dilakukan diperoleh nilai rata-rata selisih antara siswa kelas IX SMPN 3 Bengkulu Utara dan kelas IX SMPN 10 Bengkulu Utara adalah 2,32, kemudian nilai t-hitung diperoleh sebesar 1,47304027, dengan $\mathrm{df}=$ $\mathrm{n}-1$ yaitu 50-1 = 49, dengan $\alpha=0,05$ didapat $t$ tabel $=1,67655$. Dengan demikian nilai $\mathrm{t}$ hitung $<\mathrm{t}$ tebel yaitu $1,47304027<1.67655$ artinya tidak terdapat perbedaan yang signifikan antara SMPN 3 Bengkulu Utara dan SMPN 10 Bengkulu Utara.

\section{Pembahasan}

Berdasarkan hasil perhitungan frekuensi pada tabel dan diagram, dapat diketahui bahwa hasil kemampuan menulis teks tanggapan kritis siswa kelas IX SMPN 3 Bengkulu Utara adalah 59,48 yang berkategori cukup, dan siswa kelas IX SMPN 10 Bengkulu Utara adalah 62,68, yang berkategori Baik.

Pada aspek isi, siswa kelas IX SMPN 3 Bengkulu Utara memiliki rata-rata nilai 16,8 yang berkategori cukup, sedangkan pada kelas IX SMPN 10 Bengkulu Utara rata-rata 17,7 yang berkategori cukup. Hal ini menunjukkan bahwa siswa kelas IX SMPN 3 dan SMPN 10 Bengkulu Utara memiliki kemampuan yang cukup dalam menuangkan gagasan atau pikiran dalam tulisan yang disebabkan oleh pengalaman belajar serta pengetahuan yang diterima. Seperti halnya yang diungkapkan Hadiyanto (2012:23) bahwa sebuah paragraf hendaknya dibatasi hanya untuk membicarakan satu topik atau satu aspek dari sebuah topik. Karena bila tidak dipenuhinya syarat unity, atau memasukkan ide-ide yang tidak sesuai dengan ide pokoknya akan menyebabkan paragraf beresiko membingungkan pembaca.

Pada siswa kelas IX SMPN 3 Bengkulu Utara memiliki nilai rata-rata dalam aspek struktur yaitu 10,9 pada aspek struktur yang termasuk kategori cukup, sedangkan pada kelas IX SMPN 10 Bengkulu Utara memiliki nilai lebih tinggi dengan rata-rata 12,4 yang termasuk kedalam kategori cukup. Hal ini menunjukkan pada kedua SMPN ini memiliki kemampuan yang cukup dalam mengorganisasi struktur teks. Struktur teks yang di buat rata-rata tidak lengkap tetapi tersusun secara sistematis yang berarti penguasaan dan pengetahuan terhadap struktur teks masih dalam zona cukup karena kurangnya pemahaman menyusun atau cara menata organisasi yang disebabkan kurangnya latihan dalam menyusun teks tanggapan kritis teks.

Pada siswa kelas IX SMPN 3 Bengkulu Utara memiliki nilai rata-rata yaitu 12,4 pada aspek kosa kata yang berkategori cukup, sedangkan pada kelas IX SMPN 10 Bengkulu Utara memiliki nilai lebih tinggi dengan rata-rata 13,0 dengan kategori baik. Hal ini menunjukkan bahwa sebagian besar siswa SMPN 3 Bengkulu Utara untuk penguasaan kata memadai, pilihan, bentuk, dan penggunaan kata/ungkapan kadang-kadang salah namun tidak mengganggu. Sedangkan pada SMPN 10 Bengkulu Utara ini sudah mampu menguasai kosakata dalam menulis teks tanggapan kritis. Penguasaan kata yang dipakai siswa rata-rata memadai, pilihan kata dan ungkapan efektif, menguasai pembentukan kata ini disebabkan 
pembendaharaan kata serta pengalaman yang memadai, hal ini sejalan dengan pandangan Saddhono dan Slamet (2012:96) di mana seorang penulis harus menguasai banyak pembendaharaan kata untuk menyampaikan ide-ide, pengetahuan, serta pengalaman yang dimiliki.

Pada siswa kelas IX SMPN 3 Bengkulu Utara memiliki nilai rata-rata yaitu 12,3 pada aspek kalimat dengan kategori cukup, sedangkan pada kelas IX SMPN 10 Bengkulu Utara memiliki nilai lebih tinggi dengan rata-rata 13,0 dengan kategori baik, namun kedua SMP ini termasuk kedalam kategori baik. Hal ini menunjukkan bahwa sebagian besar siswa SMPN 3 Bengkulu Utara memiliki konstruksi sederhana namun efektif, terdapat kesalahan kecil pada konstruksi kompleks, terjadi sejumlah kesalahan penggunaan bahasa (fungsi/urutan kata, artikel, pronomina, preposisi) namun makna cukup jelas. Sedangkan pada SMPN 10 Bengkulu Utara memliki kalimat yang Konstruksi kompleks dan efektif, namun masih terdapat sedikit kesalahan dalam penggunaan bahasa (urutan/fungsi kata, artikel, pronomina, preposisi). Kategori baik dan cukup didapatkan sebab siswa telah paham bagaimana kalimat yang efektif agar gagasan yang disampaikan oleh penulis dapat diterima secara utuh dan tepat oleh pembaca, hal ini karena siswa memiliki pengalaman yang baik dan cukup dalam menyusun kalimat. Seperti halnya pandangan Rahardi (2009:93) bahwa kalimat efektif adalah kalimat yang dipahami entitas kebahasaan yang mampu menimbulkan kembali gagasan atau ide yang ada dalam diri penulis, persis sama dengan ide atau gagasan yang dimiliki pembacanya selain itu Hadiyanto (2012:23) juga mengungkan bahwa interelasi antara kalimat yang satu dengan kalimat lainnya, koherensi atau kepaduan merupakan syarat kedua dari sebuah paragraf yang baik. sebuah paragraf dikatakan memiliki koherensi apabila gagasa-gagasan dalam tulisan mengalir secara logis dan saling berkaitan satu sama lainnya, yang disusun menurut cara dan aturan tertentu. Kepaduan yang baik terjadi apabila ada hubungan timbal-balik antara kalimatkalimat yang membina paragraf itu. Kalimat-kalimat yang mengalir secara wajar akan mudah dipahami tanpa kesulitan.

Pada siswa kelas IX SMPN 3 Bengkulu Utara memiliki nilai rata-rata yaitu 6,6 pada aspek kalimat, sedangkan pada kelas IX SMPN 10 Bengkulu Utara memiliki nilai lebih rendah dengan rata-rata 6,7 , namun kedua SMP ini termasuk kedalam kategori cukup. Hal ini menunjukkan bahwa sebagian besar siswa kedua SMP ini memliki kemampuan mekanik yang cukup, ini artinya bahwa Kadang-kadang terjadi kesalahan ejaan, tanda baca, penggunaan huruf kapital, dan penataan paragraf, namun tidak mengaburkan makna. Kesalahan sering terjadi karena kurangnya pengalaman belajar dan pengetahuan tentang kaidah-kaidah bahasa dan ejaan.

Dilihat dari penilaian aspek-aspek kemampuan menulis siswa kelas IX SMPN 3 Bengkulu Utara dan siswa kelas IX SMPN 10 Bengkulu Utara memiliki nilai yang hampir sama, sehingga tidak terjadinya perbedaan yang begitu signifikan.

Hasil perhitungan kolmogorovsmirnov dari tabel 6 di atas dapat dilihat bahwasanya, pada SMPN 3 Bengkulu Utara diperoleh $D_{\text {maks }}=0,009359$ dan $D_{\text {tabel }}$ $=0,190$ dengan taraf signifikan $\alpha=0,05$. Jika Ho diterima dan Ha ditolak maka data berdistribusi normal dan sebaliknya jika Ho ditolak dan $\mathrm{Ha}$ diterima data berdistribusi tidak normal. Berdasarkan data yang diperoleh pada tes awal $D_{\text {maks }}<D_{\text {tabel }}$ yaitu $0,046945<0,270$ maka Ho diterima dan $\mathrm{Ha}$ ditolak sehingga data tes SMPN 3 Bengkulu Utara berdistribusi normal. 
Pada SMPN 10 Bengkulu Utara diperoleh $D_{\text {maks }}=-0,00183$ dan $D_{\text {tabel }}=$ 0,190 dengan taraf signifikan $\alpha=0,05$ pada $\mathrm{N}=50$. Berdasrakan data yang diperoleh pada tes awal $D_{\text {maks }}<D_{\text {tabel }}$ yaitu 0,00183< 0,190 maka Ho diterima dan $\mathrm{Ha}$ ditolak sehingga data SMPN 10 Bengkulu Utara yang diperoleh berdistribusi normal.

Pada SMPN 10 Bengkulu Utara diperoleh $D_{\text {maks }}=0,103034$ dan $D_{\text {tabel }}=$ 0,270 dengan taraf signifikan $\alpha=0,05$ pada $\mathrm{N}=25$. Berdasrakan data yang diperoleh pada tes awal $D_{\text {maks }}<D_{\text {tabel }}$ yaitu 0,103034 $<$ 0,220 maka Ho diterima dan Ha ditolak sehingga data tes akhir yang diperoleh berdistribusi normal.

Setelah diketahui bahwa data berdistrubusi normal maka selanjutnya dilakukan uji t-test untuk melihat apakah terdapat perbedaan. Dari perhitungan uji t yang telah dilakukan diperoleh nilai ratarata selisih antara siswa kelas IX SMPN 3 Bengkulu Utara dan kelas IX SMPN 10 Bengkulu Utara adalah 2,32, kemudian nilai t-hitung diperoleh sebesar 1,47304027, dengan $\mathrm{df}=\mathrm{n}-1$ yaitu $50-1=$ 49 , dengan $\alpha=0,05$ didapat $\mathrm{t}$ tabel $=$ 1,67655 . Dengan demikian nilai t hitung $<\mathrm{t}$ tebel yaitu $1,47304027<1.67655$ artinya tidak terdapat perbedaan yang signifikan antara SMPN 3 Bengkulu Utara dan SMPN 10 Bengkulu Utara.

Hasil penelitian ini menunjukkan bahwa siswa kelas IX SMPN 10 Bengkulu Utara memiliki nilai yang lebih tinggi dengan nilai rata-rata 62,68 yang berkategori "Baik"dari pada siswa kelas IX SMPN 3 Bengkulu Utara yaitu 59,48 yang berkategori "Cukup" namun tidak terjadinya perbedaan yang signifikan.

Banyak hal yang membuat terjadinya perbedaan ini. Sebagaimana yang diungkapkan Sri Hastuti (dalam Saddhono dan Slamet, 2012:97), bahwa kegiatan menulis merupakan kegiatan yang sangat kompleks karena melibatkan cara berpikir yang teratur dan berbagai persyaratan yang berkaitan dengan teknik penulisan, antara lain (1) adanya kesatuan gagasan, (2) penggunaan kalimat yang jelas dan efektif, (3) paragraf disusun dengan baik, (4) penerapan kaidah ejaan yang benar, dan (5) penguasa kosakata yang memadai.

Perbedaan dalam ide, ilmu pengetahuan, dan pengalaman hidup dapat mempengaruhi kualitas tulisan, karena hal ini merupakan modal dasar yang harus dimiliki dalam kegiatan menulis. Di samping itu, seorang penulis harus menguasai banyak perbendaharaan kata untuk menyampaikan ide-ide, pengetahuan, serta pengalaman yang dimiliki, karena menulis menurut Mc. Crimmon merupakan kegiatan menggali pikiran dan perasaan mengenai suatu objek, memilih hal-hal yang akan ditulis, menentukan cara menuliskannya sehingga pembaca dapat memahaminya dengan mudah dan jelas.

Namun dalam penelitian ini tidak terjadinya perbedaan yang signifikan, sehingga dapat dikatakan kedua sekolah ini memiliki kemampuan menulis yang hampir sama, namun jika dilihat dari aspek-aspek kemampuan menulis terjadi sedikit perbedaan yang dimungkinkan karena pengetahuan, pengalaman, dan ide-ide yang berbeda.

\section{PENUTUP \\ Kesimpulan}

Berdasarkan hasil penelitian dan pembahasan dengan judul skripsi "Perbedaan Kemampuan Menulis Teks Tanggapan Kritis Siswa Kelas IX SMPN 3 Bengkulu Utara dengan Siswa Kelas IX SMPN 10 Bengkulu Utara, dapat disimpulkan bahwa kemampuan menulis teks tanggapan kritis pada siswa kelas IX SMPN 3 Bengkulu Utara yaitu rata-rata 59,48 dengan kategori cukup. Artinya siswa karena siswa rata-rata cukup menguasai permasalahan, cukup memadai, pengembangan observasi 
terbatas, relevan dengan topik namun kurang rinci. Rata-rata Struktur teks siswa tidak lengkap tetapi tersusun secara sistematis. Rata-rata Penguasaan kata memadai, pilihan, bentuk, dan penggunaan kata/ungkapan kadangkadang salah namun tidak mengganggu. Rata-rata konstruksi sederhana namun efektif, terdapat kesalahan kecil pada konstruksi kompleks, terjadi sejumlah kesalahan penggunaan bahasa (fungsi/urutan kata, artikel, pronomina, preposisi) namun makna cukup jelas. Kadang-kadang siswa terjadi kesalahan ejaan, tanda baca, penggunaan huruf kapital, dan penataan paragraf, namun tidak mengaburkan makna.

Kemampuan menulis teks tanggapan kritis pada siswa kelas IX SMPN 10 Bengkulu Utara yaitu rata-rata 62,68 dengan kategori baik. Artinya siswa ratarata menguasai topik tulisan cukup memadai, substantif, pengembangan teks tanggapan kritis lengkap, relevan dengan topik yang dibahas. Rata-rata siswa memiliki struktur teks Struktur teks lengkap dan tersusun secara sistematis, terdapat sedikit kesalahan. Penguasaan kosa kata memadai, pilihan kata dan ungkapan efektif, menguasai pembentukan kata. Dalam membuat kalimat rata-rata siswa Konstruksi kompleks dan efektif, terdapat hanya sedikit kesalahan penggunaan bahasa (urutan/fungsi kata, artikel, pronomina, preposisi). Dalam mekanik, rata-rata siswa menguasai aturan penulisan, terdapat se dikit kesalahan ejaan, tanda baca, penggunaan huruf kapital, dan penataan paragraf. Selain itu siswa juga mampu menuliskan tulisannya dengan diksi dan EYD.

Tidak terdapat perbedaan yang signifikan antara siswa kelas IX SMP 3 Bengkulu Utara dengan siswa kelas IX SMP 10 Bengkulu Utara. Artinya kemampuan siswa dalam setiap aspek menulis tanggapan kritis relatif sama dengan selisih nilai 2,32 di mana SMPN 10 Bengkulu Utara lebih tinggi dari pada SMPN 3 Bengkulu Utara

\section{Saran}

Berdasarkan hasil penelitian yang dilakukan di SMPN 3 Bengkulu Utara dan di SMPN 10 Bengkulu Utara, peneliti menyampaikan beberapa saran yang berkaitan dengan penelitian ini, guna perbaikan lebi lanjut:

a) Pada SMPN 3 Bengkulu Utara semua aspek berkategori cukup. Hendaknya guru terus melatih siswa dalam kegiatan menulis teks tanggapan kritis, seperti menambah latihan-latihan menulis, latihan-latihan kosa kata dan lain sebagainya.

b) Pada SMPN 10 Bengkulu Utara terdapat tiga aspek yang berkategori cukup yaitu, isi, struktur teks dan mekanik. Ketiga hal ini adalah inti dari kegiatan menulis teks tanggapan kritis, siswa disarankan lebih mendalami apa itu teks tanggapan kritis sehingga tidak tertukar dengan teks yang lainnya yang hampir mirip dari bentuk isi dan strukur.

c) Siswa hendaknya lebih banyak lagi membaca dan memperoleh pengalaman untuk mengembangkan ide-ide siswa, karena kualitas menulis seseorang dilihat dari pola pikir yang berasal dari pengalaman, pengetahuan, fakta-fakta serta teori.

\section{DAFTAR PUSTAKA}

Arikunto, S. 2010. Prosedur Penelitian Suatu Pendekatan Praktek Edisi Revisi V. Jakarta: Rineka Cipta.

Hadiyanto. 2012. Membudayakan Kebiasaan Menulis. Jakarta: PT. Fikhati Aneska. 
Rahardi, K. 2009. Bahasa Indonesia untuk Perguruan Tinggi. Jakarta: Penerbit Erlangga.
Saddhono, K., \& Slamet, S. Y. 2012. Meningkatkan Keterampilan Berbahasa Indonesia (Teori dan Aplikasi). Bandung: KP. 